\title{
Erratum: Tracking the foreign body, a rare cause of hepatic abscess
}

Carole Dangoisse and Pierre-François Laterre*

\section{Erratum}

After publication of this Case Report [1], we noticed a mistake in the order of the authors. Carole Dangoisse was meant to be the first author on this article and Pierre-François Laterre the last author. Also there were mistakes in the affiliation and contact details for Carole Dangoisse. This has been now corrected.

Published online: 26 February 2015

\section{Reference}

1. Laterre FP, Dangoisse C. Tracking the foreign body, a rare cause of hepatic abscess. BMC Gastroenterology. 2014;14:167.

\footnotetext{
* Correspondence: pierre-francois.laterre@uclouvain.be Department of Critical Care Medicine, Cliniques Universitaires Saint Luc, Université Catholique de Louvain (UCL), Avenue Hippocrate, 10, 1200 Brussels, Belgium
}

\section{Submit your next manuscript to BioMed Central and take full advantage of: \\ - Convenient online submission \\ - Thorough peer review \\ - No space constraints or color figure charges \\ - Immediate publication on acceptance \\ - Inclusion in PubMed, CAS, Scopus and Google Scholar \\ - Research which is freely available for redistribution}

Submit your manuscript at www.biomedcentral.com/submit

( Biomed Central 